\title{
OPEN
}

\section{Author Correction: The effect of endothelial nitric oxide synthase on the hemodynamics and wall mechanics in murine arteriovenous fistulas}

\section{Daniel Pike, Yan-Ting Shiu, Yun-Fang Cho, Ha Le, Maheshika Somarathna, Tatyana Isayeva, Lingling Guo, J. David Symons, Christopher G. Kevil, John Totenhagen \& Timmy Lee}

Correction to: Scientific Reports https://doi.org/10.1038/s41598-019-40683-7, published online 12 March 2019

This Article contains an error in the Methods section under subheading 'AVF blood flow extraction' where,

"AVF blood flow extraction

Blood flow velocity over a cardiac cycle was extracted from 2D gradient echo velocity mapping scans using Segment 1.9 (Medviso SB, Lund, Sweden).”

should read:

"AVF blood flow extraction

Blood flow velocity over a cardiac cycle was extracted from 2D gradient echo velocity mapping scans using ImageJ (U.S. NIH, Bethesda, MD)."

(c) (i) Open Access This article is licensed under a Creative Commons Attribution 4.0 International License, which permits use, sharing, adaptation, distribution and reproduction in any medium or format, as long as you give appropriate credit to the original author(s) and the source, provide a link to the Creative Commons license, and indicate if changes were made. The images or other third party material in this article are included in the article's Creative Commons license, unless indicated otherwise in a credit line to the material. If material is not included in the article's Creative Commons license and your intended use is not permitted by statutory regulation or exceeds the permitted use, you will need to obtain permission directly from the copyright holder. To view a copy of this license, visit http://creativecommons.org/licenses/by/4.0/.

(c) The Author(s) 2019 